\title{
New Approaches for Controlling Pink and Spiny Bollworms through Pattern of Bio Control Agents and Chemicals on Cotton Properties
}

\author{
Mesbah, H.A. ${ }^{1}$, A.Z. El-Naggar ${ }^{2}$, A.A. Abdel- Mageed ${ }^{1}$ and Hend, M.A. Abouzaid ${ }^{2}$ \\ ${ }^{1}$ Department of Plants Protection, Faculty of Agriculture ( Saba-Bacha), Alexandria \\ University \\ ${ }^{2}$ Plant Protection Research Institute, Agriculture Research Center, Alexandria, Egypt
}

\begin{abstract}
The study was carried out on cotton variety Giza 86 during two following seasons in 2017 and 2019 at the experimental farms of the faculties of Agriculture, Saba Bacha and El-Chatby, Alexandria, Egypt. The obtained results indicated that the highest efficacy was gained by Novatrin/ Radiant ${ }^{\circledR}$ and Novatrin/ Super Mix, which decreased the incidence of Earias insulana (0.84 and 1.24 larvae /10 green bolls, in respect) and pectinophora gossypiella infestation and increased the cotton yield up to (57.8 Kent / fed). Furthermore, Novatrin/ Super Mix and Super Mix/Radiant ${ }^{\circledR}$ - achieved the lowest value of yield losses $(9.6 \%$ and $10.1 \%$, respectively) during the cotton season of 2017, in addition to the foliar treatments of Novatrin/ Super Mix/Radiant ${ }^{\circledR}$ and Super Mix/ Potasin-F/ Radiant ${ }^{\circledR}$ gave higher efficacy in reducing the level of the spiny bollworm infestation( 0.53 and 0.65 larvae /10 green bolls, respectively) in 2019 season, while the application of Novatrin/ Super Mix/Radiant ${ }^{\circledR}$ and Novatrin/Potasin-F/Radiant ${ }^{\circledR}$, increased the cotton yield $(106.2 \%$ and $84.9 \%$, in respect) resulting in decreasing yield losses during the 2019 cotton season, while the foliar application of Novatrin / Super Mix, increased cotton fiber length $(34.21 \mathrm{~mm})$, while the application of lambda - cyhalothrin and Super Mix greatly increased fiber strength (50.36 and $50.16 \mathrm{gram} /$ tex, respectively), the highest increased value of fiber micronair reading was detected for the performed application of Super Mix / Radiant ${ }^{\circledR}$ (4.88 millitex)during the 2017 cotton season, while the application of Novatrin / Potasin-F / Radiant ${ }^{\circledR}$ increased fiber length $(33.66 \mathrm{~mm})$, Novatrin / Super Mix / Radiant ${ }^{\circledR}$ treatments also increased fiber strength (45.53 gram/ tex) and the value of elongation (5.60\%), as well as, application of Novatrin / Potasin-F/ chloropyrifos increased value of fiber micronair reading (4.88 millitex) during the 2019 cotton season.
\end{abstract}

\section{INTRODUCTION}

Cotton suffers from plenty of many insect pests, bollworms, sucking insects, and leaf-eating caterpillars. Cotton bollworms cause a serious problem in the growing cotton plantations because of feeding preferentially on the fruiting structures, which are normally shed after injury (Hearn and Fitt, 1992); and can be the reason of up to $50 \%$ loss (Dhawan et al., 1998).

Control of these pests have depended exclusively on conventional insecticides which have an important role in management programs to control cotton bollworms. However, the indiscriminate use of organophosphates, carbamates and synthetic pyrethroids has created a number of problems such as resistance and pest resurgence (Bajya et al., 2010).

Fertilization or/and foliar nutrients sprays is a good tool to produce a profitable cotton crop that competes with weeds and able to out-grow and overcome the possible occurrence of resulted problems from diseases and insects damage. Foliar spray can also correct deficiencies of certain required 
nutrients in large amounts (macro-elements) and/or required in trace amounts (micro-elements) (Treshow, 1970; El-Naggar, 1998; Mesbah et al., 2000; ElNaggar, 2009).

Therefore, the present study aims to evaluate some trials as pest control measures against the common injurious pink and spiny bollworms, the applications of biofertilizer Microbin ${ }^{\circledR}$, many macro and micro foliar nutrients (Super Mix, Novatrin and Potasin $-\mathrm{F}$ ), biorational insecticide (Radiant ${ }^{\circledR}$ ), and lambdacyhalothrin, chloropyrifos as standard insecticides were evaluated for controlling the Lepidopteran bollworms on cotton plants, in addition to effect of these treatments on the cotton yield, fiber properties and yield losses were also determined.

\section{MATERIALS AND METHODS}

Field experiments were carried out at the experimental farms of two Faculties of Agriculture (Saba Bacha) and (El-Chatby) Alexandria, throughout the cotton growing seasons of 2017 and 2019. Whereas, in both seasons an area of half feddan was cultivated with cotton variety "Giza 86 " on $20^{\text {th }}$ April and $1^{\text {st }}$ May, respectively.

The experimental area was divided into plots each of 0.01 feddan. The randomized complete block design was utilized in the trial program with three and/ or four replicates for each treatment, as well as the untreated check in both seasons. Each plot was separated from the adjacent one by a half-meter belt to minimize the interference of spray drift from one treatment to another.

In the cotton seasons of 2017 and 2019, prior to planting the cotton seeds were treated with the bio-fertilizer "Microbin ${ }^{\circledR}$. . The experimental area was divided to 6 and 7 treatments in addition to an untreated check. Treatments include:1) foliar fertilizers: "Super Mix, novatrin and potasin -F; 2) synthetic insecticide lambda - cyhalothrin (Katron 5\%EC ${ }^{\circledR}$ ) and chlorpyrifos (Pestban 48\%EC ${ }^{\circledR}$ ), 3) A biopesticide "Radiant ${ }^{\circledR}$ " which was individually sprayed. The treatments were applied at three different periods, i.e., at the beginning of flowering period, the period of fifty percentage of flowering and the beginning of fruiting period.

\section{Applied treatments:}

\begin{tabular}{|c|c|}
\hline Season of 2017 & Season of 2019 \\
\hline Novitrin & Novitrin / Super Mix/ Radiant ${ }^{\circledR}$ \\
\hline Novitrin / Radiant ${ }^{\circledR}$ & Novitrin / Super Mix/ Potasin-F \\
\hline Novitrin / Super Mix & Novitrin / Potasin-F / Radiant ${ }^{\circledR}$ \\
\hline Super Mix / Radiant ${ }^{\circledR}$ & Novitrin / Potasin-F / Chloropyrifos \\
\hline Super Mix & Super Mix/ Potasin-F/ Radiant ${ }^{\circledR}$ \\
\hline Lambda - cyhalothrin & Super Mix/ Potasin-F/ lambda - cyhalothrin \\
\hline Untreated Check & chloropyrifos \\
\hline & Untreated Check \\
\hline
\end{tabular}


Inspections were carried out for determining the efficiency of the applied treatments of tested compounds against the pink and spiny bollworms $p$. gossypiella and E. insulana (Boisd) (Lepidoptera: Noctuidae). Also the side effect of treatments was on cotton fiber quality, cotton yield and yield losses investigated in both seasons.

\section{TESTED COMPOUNDS}

\section{Foliar fertilizers:}

\section{1. potasin-F:}

The main compound are: NPK $(0: 10: 30), 30 \%$ potassium oxide, $10 \%$ fivith potassium oxide.

\subsection{Novatrin}

The main components are:

$\begin{array}{llll}\mathrm{K}=5 \% & \mathrm{~N}=5 \% & \mathrm{P}=5 \% & \mathrm{Fe}=1.5 \% \\ \mathrm{Zn}=1.5 \% & \mathrm{Mn}=1 \% & \mathrm{Mo}=0.01 \% & \mathrm{~B}=0.5 \%\end{array}$

\subsection{Super Mix}

It contains micro and rare elements, a group of amino acids, magnesium and natural growth stimulants.

\section{2- Insecticides:}

\section{a. Organophosphorous insecticide:}

chlorpyrifos (Pestban 48\%EC $\left.{ }^{\circledR}\right)$; O,O-diethyl O-(3,5,6- trichloro -2 - pyridinyl phosphorothioate.

\section{b.Pyrethroide insecticide:}

Lambda cyhalothrin (KATRON 5\%EC $\left.{ }^{\circledR}\right)$; (RS)-a-cyano-3-phenoxybenzyl (Z)(1R,3R)-3-(2-chloro-3,3,3-trifluoroprop-1-enyl)-2,2dimethylcyclopropanecarboxylate.

\section{c. Biopestisides:}

\section{Spinetoram (Radiant ${ }^{\circledR} 12$ SC):}

The semi synthetic compound is the second generation of spinosyns group.

\section{Estimation of bollworms infestation}

Weekly samples of ten green bolls/plot were taken randomly; the examined bolls for each treatment were 30 and 40 green bolls in both seasons, respectively. In each taken sample, the bolls were examined externally before dissection and internal inspection. Infestation records were based on the existence of injury symptoms regardless the presence of the larvae. The level of infestation by bollworms was weekly estimated along ten or/ and nine weeks during 2017 and 2019 seasons, respectively.

\section{Cotton yield}

In each treatment, ripened open bolls from 30 and 40 cotton plants in the growing seasons of 2017 and 2019, respectively were collected to determine the rate of cotton yield per plant, from which, the total yield/feddan was relatively calculated, in accordance to the total number of growing cotton plants per feddan. 


\section{Loss assessment in cotton yield caused by bollworms}

The loss in cotton yield was assessed according to the procedure of Awad (1982), Abd El-Rahman (1999), and El-Naggar (1998 and 2003). Loss assessment was measured throughout the consequent cotton seasons 2017 and 2019. For that purpose ten cotton plants were randomized chosen in each treatment for detecting and counting the numbers of completely open bolls, $2 / 3$ and $1 / 3$ open bolls that symbolled the letters A, B and C, respectively. Also, green and dry bolls were transferred to laboratory for examining and counting the number of infested dry bolls (D) and green bolls (E). Then, the expected open bolls $(F)$ were calculated as follows:

$$
F=A+B+C+D+E
$$

Also the true opened bolls $(\mathrm{G})$ were calculated as follows:

$$
\mathbf{G}=\mathbf{A}+\left(\mathrm{B} \mathrm{x}^{2 / 3}\right)+(\mathbf{C} \times 1 / 3)
$$

Then, the number of the unopened bolls $(H)$ was calculated as follows:

$$
\mathbf{H}=\mathbf{F}-\mathbf{G}
$$

The percentage of loss (I) was estimated according to the following equation:

Fiber quality

$$
\% \text { Loss }(I)=H / F \times 100
$$

At the end of each growing season, cotton samples of $0.5 \mathrm{~kg}(500 \mathrm{~g})$ collected from each replicate that finally equaled the representative sample for each treatment (1.5) $\mathrm{kg}$ were ginned; then these samples were transferred to the Cotton Arbitration and Testing General Organization (CATGO) Spinning and Fiber sector for estimating and determining the properties of fiber quality (lint length $\mathrm{mm}$., fineness, tenacity and elongation) by HVI instrument.

\section{Statistical Analysis}

Data were subjected to the analysis of variance test (ANOVA), with mean separation at $5 \%$ levels of significance, Computer program COSTAT and Duncan's Multiple Rang Test was used to compare the averages according to the method of Snedecor and Cochran (1967).

\section{RESULT AND DISCUSSION}

The combined effect of bio-fertilizers, foliar sprays and certain insecticides on the incidence of spiny cotton bollworm infestation throughout the growing cotton seasons of 2017 and 2019.

Results in Table (1) show the effect of each of the performed foliar treatments in season- 2017 on the bio-fertilized cotton plants on the mean numbers of inspected spiny bollworm larvae /10 green bolls. It could be noticed that, each of the subsequently performed sprays of Novatrin / Radiant ${ }^{\circledR}$ were highly efficient and gave the utmost lower level of infestation amounted to 0.84 larvae $/ 10$ bolls, compared to the other applied foliar treatments which gave a more or less increased infestation calibrated from 1.24 larvae / 10 bolls for Novatrin / Super Mix or/ and Super Mix alone to 1.45 larvae / 10 bolls for Novatrin: Remarked, the measured level of the spiny bollworm infestation in the untreated check was higher 
than that calculated for each of aforementioned treatments and comprised 1.75 larvae / 10 bolls.

Moreover, the obtained results in season-2019, show the response of biofertilized cotton plants to the detected effect of each performed foliar treatment on the calculated means of inspected spiny bollworm larvae / 10 bolls. From Table (1), it could be also revealed that each of the applied sprayings of Novatrin / Super Mix/ Radiant ${ }^{\circledR}$ gave a highly efficient control of the spiny bollworm (0.53 larvae / 10 bolls), followed by ( 0.65 larvae / 10 bolls) in case of following spraying of Super Mix/ Potasin-F/ Radiant ${ }^{\circledR}$. For the other consequently applied foliar treatments, the rate of the spiny bollworm infestation calibrated between 0.71 larvae / 10 bolls for Novatrin / Potasin-F / Radiant ${ }^{\circledR}$ and 1.09 larvae / 10 bolls for Novatrin / Super Mix/ Potasin-F. Comparatively the untreated check gave a high level of spiny bollworm infestation amounted to 1.71 larvae / 10 bolls.

Table (1). The combined effect of tested bio-fertilizer and foliar treatments on mean numbers of Earias insulana larvae per ten bolls throughout the growing seasons of 2017 and 2019

\begin{tabular}{|c|c|}
\hline Treatments & Mean Numbers of larvae / 10 bolls \\
\hline \multicolumn{2}{|c|}{ Season of 2017} \\
\hline Novitrin & $1.45^{b}$ \\
\hline Novitrin / Radiant ${ }^{\circledR}$ & $0.84^{c}$ \\
\hline Novitrin / Super Mix & $1.24^{b}$ \\
\hline Super Mix / Radiant ${ }^{\circledR}$ & $1.27^{\mathrm{b}}$ \\
\hline Super Mix & $1.24^{b}$ \\
\hline Lambda - cyhalothrin & $1.42^{b}$ \\
\hline Untreated Check & $1.75^{\mathrm{a}}$ \\
\hline LSD $_{.05}$ & 0.29 \\
\hline Significant & $* * *$ \\
\hline \multicolumn{2}{|c|}{ Season of 2019} \\
\hline Novitrin / Super Mix/ Radiant ${ }^{\circledR}$ & $0.53^{d}$ \\
\hline Novitrin / Super Mix/ Potasin-F & $1.09^{b}$ \\
\hline Novitrin / Potasin-F / Radiant ${ }^{\circledR}$ & $0.71^{\mathrm{bcd}}$ \\
\hline Novitrin / Potasin-F / Chloropyrifos & $0.78^{\mathrm{bcd}}$ \\
\hline Super Mix/ Potasin-F/ Radiant ${ }^{\circledR}$ & $0.65^{\mathrm{cd}}$ \\
\hline Super Mix/ Potasin-F/ lambda - cyhalothrin & $1.06^{\mathrm{bc}}$ \\
\hline chloropyrifos & $1.03^{\mathrm{bc}}$ \\
\hline Untreated Check & $1.71^{\mathrm{a}}$ \\
\hline LSD. $_{.05}$ & 0.37 \\
\hline Significant & 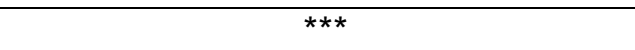 \\
\hline
\end{tabular}

Means followed by the same latter are not significantly different at the $5 \%$ level by DMRT ${ }^{* * *}=$ highly Significant $(0.001)$ 
The combined effect of bio-fertilizers, foliar sprays and certain insecticides on the incidence of pink cotton bollworms infestation throughout the growing cotton seasons of 2017 and 2019

Results of treatments during both seasons are illustrated in Table 2, and expressed as mean numbers of pink bollworm larvae per 10 green bolls. It can be revealed the significant differences between most of the calculated means of pink bollworm / 10 bolls in all of the run treatments and the untreated in plants control, which indicated a relatively equal level of infestation, comprised 0.63 larvae / 10 bolls.

Herein, the adopted sequences of Novatrin / Super Mix and Novatrin / Radiant ${ }^{\circledR}$ gave lowest levels of the pink bollworm infestation ranged from 0.03 to 0.09 larvae / 10 bolls, respectively. For the other tested foliar sprays, the estimated lower levels of the pink bollworm infestation to a less extent, increased up to 0.27 larvae / 10 bolls in case of lambda - cyhalothrin, while, for the other evaluated foliar treatments of Novatrin, Super Mix or /and Super Mix / Radiant ${ }^{\circledR}$ these lower means numbers amounted to $0.12,0.15$ and 0.18 larvae / 10 bolls, in respect (Table 2).

In 2019, it was clear that, there was no infestation by the pink bollworm. Herein the calculated means of counted larvae per treatment were comparatively utmost low or negligible and didn't have any clear indications about the efficient role of the tested foliar or /and alternative chemicals.

That may be attributed to the limited dispersion and lower density of the pink bollworm population in the locality of the experimental Research Farm of the faculty of Agriculture (El.Chatby) in Alexandria Governorate.

Table (2). Effect of performed foliar sprays on mean number of pectinophora gossypiella larvae per ten bolls throughout the growing seasons of 2017

\begin{tabular}{cc}
\hline Treatments & Mean Numbers of larvae / 10 bolls \\
\hline Novitrin & $0.12^{\mathrm{bc}}$ \\
Novitrin / Radiant $\mathrm{t}^{\Theta}$ & $0.09^{\mathrm{c}}$ \\
Novitrin / Super Mix & $0.03^{\mathrm{c}}$ \\
Super Mix / Radiant ${ }^{\Theta}$ & $0.18^{\mathrm{bc}}$ \\
Super Mix & $0.15^{\mathrm{bc}}$ \\
lambda - cyhalothrin & $0.27^{\mathrm{b}}$ \\
Untreated Check & $0.63^{\mathrm{a}}$ \\
LSD.05 & 0.15 \\
\hline Significant & ${ }^{* *}$ \\
\hline Means followed by the same latter are not significantly different at the $5 \%$ level by DMRT
\end{tabular}


Which is mostly cultivated by the conventional field crops, in particular, the more palatable corn plants to this insect-pest. Besides, the existing of ordinary vegetables cultivation, especially tomato, okra and other legumes which are considered utmost preferable and palatable host plants to the insect-pest.

These above mentioned results of pink and spiny bollworms were ascertained by the findings of many workers. Whereas, in the present work the application of insecticides and bio-insecticides gave high efficiency on the occurrence of the pink and spiny bollworms infestation, and was in agreement with the concluded results by Wei et al. (2018) who found that spinetoram showed an excellent activity against $H$. armigera, especially, against Bt (Cry1Ac) resistant $H$. armigera under laboratory conditions. Also Eman et al. (2018) stated that Spinosad was the effective toxin against the neonate larvae of the pink bollworm, Pectinophora gossypiella (Saund.), under laboratory conditions, followed by chlorpyrifos, lambda-cyhalothrin then Methomyl.

Results also proved the high efficiency of the evaluated foliar fertilizers and/ or bio-fertilizer as efficient control agents against the bollworms which are in agreement with those recorded by El-Naggar et al. (2008) who found that the applied tri and / or bi - sequent sprays of Baythroid ${ }^{\circledR}$ with Greenzit N.P.K and Neem oil with Greenzit S.P 100 efficiently decreased the rate of spiny bollworm infestation. Also, Chandramani et al. (2010) revealed that the combination of FYM, lignite fly ash and neem cake applied in splits doses, significantly reduced leaf hopper populations, compared to the applied NPK as inorganic form on paddy. Gogi et al. (2012) observed that nutrient management improves plant health, which enables the plant to tolerate the incidence of herbivores sucking as well as chewing insectpests. Torres-Olivar et al. (2014) elucidated that fluctuation in the nitrate $\left(\mathrm{NO}_{3}{ }^{-}\right)$ application can increase the susceptibility of plants to insect-pests as its excessive use decreases lignin concentration, which is a substance used by plants as a physical defense against various insect-pests. In addition, Kiran et al. (2018) found that the need for more healthful foods is stimulating the development of new techniques to increase plant resistance to phytophagous insects.

Result also revealed, that the application of foliar fertilizers with bioinsecticides was highly effective on the incidence of the bollworms. In this concern, El-Naggar (2009) stated that the foliar treatment with Easterna Aminofert / Greenzit S.P $P_{100} /$ Spinosad decreased the incidence of spiny bollworm infestation in cotton season 2006. The foliar treatments of Easterna / Greenzit S.P 100 with Spinosad or / and Chlopyrifos were also high efficient in reducing the level of spiny bollworm infestation in season 2007.

The combined effect of bio-fertilizers, foliar sprays and certain insecticides on the cotton yield in the growing seasons of 2017 and 2019

Data in Table 3 exhibit effects of different performed foliar spraying treatments in season 2017 on the cotton yield, expressed as a percentage of increase, compared to that of untreated check. It could be concluded that the 
applied sprays of Novatrin / Radiant ${ }^{\circledR}$ and Novatrin/ Super Mix gave the highest rate of cotton yield increase, which comprised $57.8 \%$ and followed by the applied foliar treatment of Super Mix/ Radiant ${ }^{\circledR}$ which gave a relatively high increase of cotton yield amounted to15.7\%. While Novatrin, Super Mix and lambda- cyhalothrin gave less high rates of cotton yield (5.2\%) but still higher than that of the untreated check.

Table (3). Effect of bio-fertilizer and tested foliar treatments on the yield of cotton in the growing seasons of 2017

\begin{tabular}{ccc}
\hline Foliar treatments & $\begin{array}{c}\text { Weight / Feddan } \\
\text { Kg (Kent.) }\end{array}$ & $\begin{array}{c}\% \\
\text { Increase }\end{array}$ \\
\hline Novitrin & $1104 \mathrm{~kg}$ (7 Kent) & 5.2 \\
Novitrin / Radiant $^{\circledR}$ & $1656 \mathrm{~kg}(10.5 \mathrm{Kent})$ & 57.8 \\
Novitrin / Super Mix & $1656 \mathrm{~kg}(10.5 \mathrm{Kent})$ & 57.8 \\
Super Mix / Radiant ${ }^{\circledR}$ & $1214.4 \mathrm{~kg}(7.7 \mathrm{Kent})$ & 15.7 \\
Super Mix & $1104 \mathrm{~kg}$ (7 Kent) & 5.2 \\
lambda - cyhalothrin & $1104 \mathrm{~kg}$ (7 Kent) & 5.2 \\
Untreated Check & $1048.8 \mathrm{~kg}$ (6.6 Kent) \\
${ }^{*}$ expressed as \% of increase than the untreated check, according to Hussein et al. (2002).
\end{tabular}

Similarly, results in Table 4 elucidated the profitable effect of performed foliar treatments on the cotton yield in season 2019, expressed as a percent of increase than that of the untreated check. It could be noticed that the subsequent treatment of Novatrin / Super Mix/ Radiant ${ }^{\circledR}$ gave the highest increase of cotton yield (106.2\%), followed by Novatrin / Potasin-F / Radiant ${ }^{\Theta}(84.9 \%)$. Other foliar treatments gave more or less increase of cotton yield ranged from $25.2 \%$ for Super Mix/ Potasin-F/ lambda -cyhalothrin to59.3\% for Novatrin / Super Mix/ Potasin-F.

Results in the present work declare that the performed applications of insecticides and / or bioinsecticides increased the yield of cotton plants. These results are in agreement with those mentioned by El- Tabbakh (2002) who reported that the number of bolls /plant and seed cotton yield per plant were higher in case of treatment with the insecticides: Actellic, Durspan and Larvin. Also Abdel Rahman (2004) found that Tracer ${ }^{\circledR}$, Dursban $\AA$, Runner ${ }^{\circledR}$ and Achook ${ }^{\circledR}$ treatments increased the cotton yield as compared with the untreated treatment.

Result also showed that the application of foliar fertilizers and bio-fertilizer increased cotton yield and are in agreement with those showed by Ramalakshmi and Raj (2008) who reported on the influence of the inoculation of Azospirillum, phosphobacteria, Azophos (rice husk ash) and mycorrhiza on rainfed $\left(\mathrm{KC}_{2}\right)$ cotton. The biofertilizers inoculation significantly increased the root length, shoot length, boll number and boll weight of cotton, Kumar et al. ( 2017) explained that, the need for the use of biofertilizer arises primarily for two reasons: first): because increase 
in the use of fertilizers leads to increased crop productivity and second): because increased usage of chemical fertilizer leads to damage in soil texture

\section{Table (4). Effect of bio-fertilizer and tested foliar treatments on the yield of cotton in the growing seasons of 2019}

\begin{tabular}{|c|c|c|}
\hline Foliar treatments & $\begin{array}{l}\text { Weight / Feddan } \\
\text { (Kent.) }\end{array}$ & $\begin{array}{c}\% \\
\text { Increase* }\end{array}$ \\
\hline Novitrin / Super Mix/ Radiant ${ }^{\circledR}$ & 2104.2 (13.3 Kent) & 106.2 \\
\hline Novitrin / Super Mix/ Potasin-F & 1625.4 (10.3 Kent) & 59.3 \\
\hline Novitrin / Potasin-F / Radiant ${ }^{\circledR}$ & 1886.4 (11.9 Kent) & 84.9 \\
\hline Novitrin / Potasin-F / chloropyrifos & 1414.8 (8.9 Kent) & 38.7 \\
\hline Super Mix/ Potasin-F/ Radiant ${ }^{\circledR}$ & 1314 (8.3 Kent) & 28.8 \\
\hline Super Mix/ Potasin-F/ lambda - cyhalothrin & 1278 (8.1 Kent) & 25.2 \\
\hline chloropyrifos & 1470.6 (9.3 Kent) & 44.1 \\
\hline Untreated Check & 1020 (6.48 Kent) & \\
\hline
\end{tabular}

and raises other environmental problems. Also, El Sabagh et al. (2018) proved that foliar application of ascorbic acid or salicylic acid on cotton plants at flowering initiation stage and at peak of flowering stage had significant positive effects on seed cotton yield and lint quality properties. In addition, Kranthi and Stone (2020) showed that yield trend of cotton in India was highly correlated with the increase in the fertilizer application in India.

Moreover, the obtained resulted also revealed, that the application of foliar fertilizers with bio-insecticides increased cotton yield and are in accordance with those detailed in the works of Mesbah et al. (2009) who explained that the attained cotton yield was significantly higher in organic cotton $(89.20 \%)$ post application of the $4^{\text {th }}$ IPM program $(1 / 2 \mathrm{~g} /$ liter) of each Ascorbic, Salicylic acid at the start of flowering period, Trichogramma, Agerin + Achook, Trichogramma + Agerin + Achook, Spinosad + Meenark, Dipel + Meenrak during boll formation). Similar results were also reported by El - Naggar (2009) who found that the application of Eastrena followed by Super Biovert and Spinosad increased the cotton yield compared to the untreated control.

\section{Efficiency of bio-fertilizer and foliar applications on the yield losses of cotton plants during seasons of 2017 and 2019}

Table (5) shows the effect of applied foliar treatments on yield losses of grown cotton plants from the treated seeds with the used bio-fertilizer-Microbin ${ }^{\circledR}$ in season, 2017. The measured yield losses in different preformed foliar treatments had been calculated as percentages of the remaining green and/or dry bolls after ginning the yield of opened bolls of each treatment. From the Table, it could be obviously seen that treatments of Novatrin / Super Mix and Super Mix / Radiant ${ }^{\circledR}$ gave the lowest values of 
Table (5). Effect of foliar spraying on yield losses of cotton plants during season of 2017

\begin{tabular}{cccccccccc}
\hline Treatments & $\begin{array}{c}\text { Non } \\
\text { Infested } \\
\text { boll } \\
(\mathbf{A})\end{array}$ & $\begin{array}{c}\mathbf{2 / 3} \\
\text { open } \\
\text { bolls } \\
\text { (B) }\end{array}$ & $\begin{array}{c}\mathbf{1 / 3} \\
\text { open } \\
\text { bolls } \\
\text { (C) }\end{array}$ & $\begin{array}{c}\text { Infested } \\
\text { dry } \\
\text { bolls } \\
\text { (D) }\end{array}$ & $\begin{array}{c}\text { Infested } \\
\text { green } \\
\text { bolls } \\
\text { (E) }\end{array}$ & $\begin{array}{c}\text { Expected } \\
\text { open } \\
\text { bolls } \\
\text { (F) }\end{array}$ & $\begin{array}{c}\text { True } \\
\text { open } \\
\text { bolls } \\
\text { (G) }\end{array}$ & $\begin{array}{c}\text { Unopened } \\
\text { bolls } \\
\text { (H) }\end{array}$ & $\begin{array}{c}\text { Loss } \\
\text { (I) }\end{array}$ \\
\hline $\begin{array}{c}\text { Novitrin } \\
\text { Novitrin / }\end{array}$ & 122 & 45 & 50 & 15 & 10 & 194 & 169 & 25 & 12.8 \\
$\begin{array}{c}\text { Radiant } \\
\text { Novitrin / }\end{array}$ & 182 & 47 & 44 & 12 & 14 & 254 & 228 & 26 & 10.2 \\
$\begin{array}{c}\text { Super Mix } \\
\text { Super Mix / } \\
\text { Radiant }\end{array}$ & 178 & 51 & 35 & 19 & 5 & 248 & 224 & 24 & 9.6 \\
$\begin{array}{c}\text { Super Mix } \\
\text { Lambda- }\end{array}$ & 140 & 39 & 36 & 13 & 7 & 198 & 178 & 20 & 10.1 \\
$\begin{array}{c}\text { cyhalothrin } \\
\text { Untreated } \\
\text { Check }\end{array}$ & 124 & 35 & 43 & 15 & 6 & 186 & 165 & 21 & 11.2 \\
\hline
\end{tabular}

yield losses comprising $9.6 \%$ and $10.1 \%$, respectively; followed by Novatrin / Radiant $^{\circledR}$, Super Mix, Novatrin and lambda - cyhalothrin $(10.2 \%, 11.2 \%, 12.8 \%$ and $13.6 \%$, in respect); the highest estimated value of yield loss (41.4\%) was recorded for the untreated check.

Identically, results of season 2019, exhibited in Table (6) showed the calculated yield losses of growing cotton plants in season 2019. It could be also revealed that the calculated value of yield losses in the treatment of Novatrin / Potasin-F / Radiant ${ }^{\circledR}$ was the lowest $(5.6 \%)$, followed by treatments of :Novatrin / Super Mix/ Radiant ${ }^{\circledR}(6.4 \%)$ and Novatrin / Potasin-F / chloropyrifos (7.3\%). For the other tested foliar treatments the percentages of yield losses calibrated from $15.6 \%$ for chloropyrifos to $17.3 \%$ for Super Mix/ Potasin-F/ Radiant ${ }^{\circledR}$, but still lower the estimated losses of the untreated check $(26.8 \%)$.

The above results of the effects of applied bio-fertilizer and foliar treatments indicated the lower yield losses, in comparison to the untreated control. That was ascertained by the obtained results of many workers, i.e., the stated results by ElNaggar (1998) and Mesbah et al. (2000) who determined that the application of bio-fertilizers and / or the consequent sprays of Polytrin ${ }^{\circledR}$ with Greenzit S.P $P_{100}$ or / and polymex / Ascorbic acid gave the lowest values of yield losses, Abdel-Aziz and Mahasen(2002) found that the spraying of both of the evaluated foliars: Potassium foliar fertilizer (38\% Potassium) and Potasin- $\mathrm{F}$; in addition to a sequent spraying with ascorbic acid and salicylic acid in greenhouse and field trials had a significant effect in reducing the economic loss of cotton yield, compared to the untreated check. 
Also, Balakrishnan et al. (2005) declared that the different evaluated management modules exhibited the greatest reduction in bollworm

Table (6). Effect of foliar spraying on yield losses of cotton plants during season of 2019

\begin{tabular}{|c|c|c|c|c|c|c|c|c|c|}
\hline Treatments & $\begin{array}{c}\text { Non } \\
\text { Infested } \\
\text { boll } \\
\text { (A) }\end{array}$ & $\begin{array}{c}2 / 3 \\
\text { open } \\
\text { bolls } \\
\text { (B) }\end{array}$ & $\begin{array}{c}1 / 3 \\
\text { open } \\
\text { bolls } \\
\text { (C) }\end{array}$ & $\begin{array}{c}\text { Infested } \\
\text { dry } \\
\text { bolls } \\
\text { (D) }\end{array}$ & $\begin{array}{c}\text { Infested } \\
\text { green } \\
\text { bolls } \\
(\mathrm{E})\end{array}$ & $\begin{array}{c}\text { Expected } \\
\text { open } \\
\text { bolls } \\
\text { (F) }\end{array}$ & $\begin{array}{c}\text { True } \\
\text { open } \\
\text { bolls } \\
\text { (G) }\end{array}$ & $\begin{array}{c}\text { Unopened } \\
\text { bolls } \\
\text { (H) }\end{array}$ & $\begin{array}{l}\% \\
\text { Loss } \\
\text { (I) }\end{array}$ \\
\hline $\begin{array}{l}\text { Novitrin / Super } \\
\text { Mix/ Radiant }^{\circledR}\end{array}$ & 820 & 30 & 12 & 39 & 1 & 902 & 844 & 58 & 6.4 \\
\hline $\begin{array}{l}\text { Novitrin / Super } \\
\text { Mix/ Potasin-F } \\
\text { Novitrin / }\end{array}$ & 673 & 9 & 16 & 129 & 0 & 827 & 684 & 143 & 17.2 \\
\hline $\begin{array}{l}\text { Potasin-F / } \\
\text { Radiant }^{\circledR} \\
\text { Novitrin / }\end{array}$ & 783 & 8 & 6 & 40 & 0 & 837 & 790 & 47 & 5.6 \\
\hline $\begin{array}{l}\text { Potasin-F / } \\
\text { Chloropyrifos } \\
\text { Super Mix/ }\end{array}$ & 720 & 9 & 5 & 50 & 2 & 786 & 728 & 58 & 7.3 \\
\hline $\begin{array}{l}\text { Potasin-F/ } \\
\text { Radiant }^{\circledR}\end{array}$ & 450 & 7 & 6 & 90 & 0 & 553 & 457 & 96 & 17.3 \\
\hline $\begin{array}{c}\text { Super Mix/ } \\
\text { Potasin-F/ } \\
\text { lambda- } \\
\text { cyhalothrin }\end{array}$ & 470 & 6 & 2 & 92 & 0 & 570 & 475 & 95 & 16.7 \\
\hline chloropyrifos & 380 & 9 & 6 & 63 & 2 & 460 & 388 & 72 & 15.6 \\
\hline $\begin{array}{l}\text { Untreated } \\
\text { Check }\end{array}$ & 420 & 12 & 14 & 146 & 0 & 592 & 433 & 159 & 26.8 \\
\hline
\end{tabular}

infestation. They found that the TNAU (Tamil Nadu Agricultural university) module included the application of neem cake (250 kg / ha), acid delinting of seeds, seed treatment with bio-fertilizers and biological control agents (Trichoderma viride at 4 $\mathrm{g} / \mathrm{kg}$ seeds and pseudomonas fluorescens at $10 \mathrm{~g} / \mathrm{kg}$ seeds), intercropping with cowpea, sunflower, green gram, black gram, cucumber and okra, border cropping with maize and castor beans, and use of pheromone and yellow sticky traps recorded the lowest boll damage.

Efficiency of tested bio-fertilizer and foliar applications on the fiber properties of the grown cotton plants during seasons of 2017 and 2019

The data in Table (7) shows the effect of each of performed foliar treatments in season 2017 on the grown plants from the bio-fertilized cotton seeds, in concern to the estimated parameters of fiber quality of ginned cotton. From the Table, it could be noticed that the following application of Novatrin / Super Mix , to less extent , increased cotton fiber length $(34.21 \mathrm{~mm})$ in comparison to the untreated check $(32.18 \mathrm{~mm})$; the treatments of Super Mix / $\operatorname{Radiant}^{\Theta}$ and Super Mix were least efficient and recorded 31.97 and $31.7 \mathrm{~mm}$, in respect. The other applied treatments, showed merely similar and insignificant different values between them 
and the untreated check, amounted to $(32.99 \mathrm{~mm})$ for Novatrin / Radiant ${ }^{\circledR}$, $(32.30 \mathrm{~mm})$ for Novatrin and $(32.24 \mathrm{~mm})$ for lambda - cyhalothrin.

For the measured property of fiber strength ( $g / t e x)$, the application of lambda - cyhalothrin or land Super Mix greatly increased fiber tenacity up to 50.36and 50.16 (g/tex), in respect, followed by Novatrin / Super Mix and Super Mix / Radiant ${ }^{\circledR}-48$ and $47.73(\mathrm{~g} / \mathrm{tex})$, in respect. While, the application of Novatrin and Novatrin / Radiant ${ }^{\circledR}$ to a more extent, decreased fiber strength up to 45.8 and45.6 (g/tex), respectively, in comparison to the untreated check - 48.4(g/tex).

Table (7). Effect of foliar spray on the fiber properties of the grown cotton plants throughout the growing season of 2017

\begin{tabular}{|c|c|c|c|c|}
\hline Treatments & $\begin{array}{c}\text { Length } \\
2.5 \% \text { S.L. } \\
\mathrm{mm}\end{array}$ & $\begin{array}{c}\text { Strength } \\
\text { g / Tex }\end{array}$ & $\begin{array}{c}\text { Elongation } \\
\%\end{array}$ & $\begin{array}{c}\text { Micronair } \\
\text { Reading }\end{array}$ \\
\hline Novitrin & $32.30^{\mathrm{bc}}$ & $45.8^{c}$ & 6.33 & $4.55^{\mathrm{bc}}$ \\
\hline Novitrin / Radiant $^{\circledR}$ & $32.99^{b}$ & $45.6^{c}$ & 6.6 & $4.59^{\mathrm{bc}}$ \\
\hline Novitrin / Super Mix & $34.21^{a}$ & $48^{\mathrm{b}}$ & 6.03 & $4.49^{c}$ \\
\hline Super Mix / Radiant ${ }^{\circledR}$ & $31.97^{c}$ & $47.73^{b}$ & 7.1 & $4.88^{a}$ \\
\hline Super Mix & $31.7^{\mathrm{c}}$ & $50.16^{a}$ & 7.03 & $4.68^{b}$ \\
\hline lambda - cyhalothrin & $32.24^{\mathrm{bc}}$ & $50.36^{a}$ & 6.6 & $4.60^{\mathrm{bc}}$ \\
\hline Untreated Check & $32.18^{\mathrm{bc}}$ & $48.4^{\mathrm{ab}}$ & 6.33 & $4.48^{c}$ \\
\hline LSD $_{.05}$ & 0.84 & 1.92 & & 0.17 \\
\hline Significant & $* * *$ & $* * *$ & N.S & ** \\
\hline
\end{tabular}

Means followed by the same letter (s) are not significantly different at the $5 \%$ level.

N.S. Not significant $\quad{ }^{* *}=$ highly significant

Elongation\% was insignificantly affected by all of the carried out foliar treatments, and ranged from 6.03 to $7.1 \%$ in comparison with the untreated check $(6.33 \%)$ (Table 7$)$.

Moreover, the results obviously showed that the higher increased value of fiber micronair reading 4.88 (millitex) was detected for the performed application of Super Mix / Radiant ${ }^{\Theta}$, followed by Super Mix- 4.68 (millitex). Comparatively, the grown plants of untreated control indicated decreased value of 4.48 (millitex). While, in other conducted foliar applications: lambda - cyhalothrin, Novatrin / Radiant ${ }^{\circledR}$ and Novatrin that value of micronair reading amounted to $4.60,4.59$ and 4.55 (millitex), respectively.

Similar results in Table 8 declare the determined effects of performed foliar treatments during season 2019 on the estimated parameters of fiber quality of ginned cotton. Comparatively, it could be noticed from the Table that the application of the consequent foliar spraying of Novatrin / Potasin-F / Radiant ${ }^{\circledR}$, chloropyrifos, Novatrin / Super Mix/ Potasin-F, Super Mix/ Potasin-F/ Radiant ${ }^{\circledR}$ and Novatrin / Potasin-F /chloropyrifos, in a less extent, increased fiber length up to$33.66,33.54,33.45,33.31$ and $33.08(\mathrm{~mm})$, in respect, and were equally efficient with the untreated check $-33.25 \mathrm{~mm}$. Followed by Super Mix/ Potasin-F/ lambda - 
cyhalothrin - 32.91(mm) versus the treatment of Novatrin / Super Mix/ Radiant ${ }^{\circledR}$ which decreased this value up to $32.08(\mathrm{~mm})$.

The application of Novatrin / Super Mix / Radiant ${ }^{\circledR}$ increased fiber strength (45.53 g/tex); followed by the foliar treatments of Novatrin / Super Mix/ Potasin-F and Novatrin / Potasin-F / Radiant ${ }^{\circledR} 45.1$ and 44.9 (g/tex), respectively. The treatment of chloropyrifos decreased that measured value of fiber strength up to 43.63(g/tex), compared with the untreated check

Table (8). Effect of foliar spray on the fiber properties of the grown cotton plants throughout the growing season of 2019

\begin{tabular}{|c|c|c|c|c|}
\hline Treatments & $\begin{array}{c}\text { Length } \\
2.5 \% \text { S.L. } \\
\text { mm }\end{array}$ & $\begin{array}{c}\text { Strength } \\
\text { g / Tex }\end{array}$ & $\underset{\%}{\text { Elongation }}$ & $\begin{array}{l}\text { Micronair } \\
\text { Reading }\end{array}$ \\
\hline Novitrin / Super Mix/ Radiant ${ }^{\circledR}$ & $32.08^{b}$ & $45.53^{\mathrm{a}}$ & $5.60^{\mathrm{a}}$ & $4.87^{\mathrm{a}}$ \\
\hline Novitrin / Super Mix/ Potasin-F & $33.45^{\mathrm{a}}$ & $45.1^{\mathrm{ab}}$ & $5.60^{\mathrm{a}}$ & $4.83^{\mathrm{a}}$ \\
\hline Novitrin / Potasin-F / Radiant ${ }^{\circledR}$ & $33.66^{\mathrm{a}}$ & $44.9^{\mathrm{ab}}$ & $5.53^{\mathrm{a}}$ & $4.76^{\mathrm{ab}}$ \\
\hline $\begin{array}{l}\text { Novitrin / Potasin-F/ } \\
\text { Chloropyrifos }\end{array}$ & $\underset{a}{33.08}$ & $44.66^{\mathrm{abc}}$ & $5.5^{\mathrm{ab}}$ & $4.88^{\mathrm{a}}$ \\
\hline Super Mix/ Potasin-F/ Radiant ${ }^{\Theta}$ & $33.31^{\mathrm{a}}$ & $44.60^{\mathrm{bc}}$ & $5.46^{\mathrm{ab}}$ & $4.72^{\mathrm{ab}}$ \\
\hline $\begin{array}{l}\text { Super Mix/ Potasin-F/ lambda- } \\
\text { cyhalothrin }\end{array}$ & $\underset{\mathrm{ab}}{32.91}$ & $43.83^{\mathrm{cd}}$ & $5.30^{\mathrm{bc}}$ & $4.83^{\mathrm{a}}$ \\
\hline chloropyrifos & $33.54^{\mathrm{a}}$ & $43.63^{d}$ & $5.23^{c}$ & $4.64^{b}$ \\
\hline Untreated Check & $33.25^{\mathrm{a}}$ & $43.43^{d}$ & $5.23^{c}$ & $4.85^{\mathrm{a}}$ \\
\hline $\mathrm{LSD}_{.05}$ & $\underset{*}{0.86}$ & 0.88 & 0.21 & 0.15 \\
\hline Significant & ${ }^{*}$ & ${ }^{\star *}$ & & \\
\hline
\end{tabular}

(43.43 g/tex). The other treatments of Novatrin / Potasin-F /chloropyrifos( 44.66 g/tex) , Super Mix/ Potasin-F/ Radiant ${ }^{\circledR}$ (44.60 g/tex) and Super Mix/ Potasin-F/ lambda - cyhalothrin (43.83 $\mathrm{g} / \mathrm{tex})$ were the less efficient ones, but higher than the untreated check.

Also, the foliar treatments of Novatrin / Super Mix/ Radiant ${ }^{\circledR}$ and Novatrin / Super Mix/ Potasin-F indicated a similar effect on the measured value of elongation, which comprised $5.60 \%$. Followed by Novatrin / Potasin-F / Radiant ${ }^{\circledR}$ $(5.53 \%)$, Novatrin / Potasin-F /chloropyrifos and Super Mix/ Potasin-F/ Radiant ${ }^{\circledR}$ (5.5\% and 5.46\%, respectively) the treatment of Super Mix/ Potasin-F/ lambda cyhalothrin was less effective but higher than the untreated check (5.30\%). While, the treatment of chloropyrifos was the least efficient one $-5.23 \%$, like the untreated check $5.23 \%$.

Moreover, it could be seen from the table that the application of each of the treatments of Novatrin / Potasin-F/ chloropyrifos, Novatrin / Super Mix/ Radiant ${ }^{\circledR}$, Super Mix/ Potasin-F/ lambda - cyhalothrin and Novatrin / Super Mix/ Potasin-F gave increased values of Micronair reading (4.88, 4.87, 4.83 and 4.83(millitex), in 
respect); which were merely equally efficient with the untreated check 4.85 (millitex). Followed by Novatrin / Potasin-F / Radiant ${ }^{\circledR}$ and Super Mix/ PotasinF/ Radiant ${ }^{\circledR}$ (4.76 and 4.72 (millitex), respectively). Vice versa the treatment of chloropyrifos decreased this value up to 4.64 (millitex).

The former above elucidated results of fiber properties prove that the application of foliar nutrients, bio-fertilizer, insecticides and/ or bioinsecticides, in a more or a less extent, increased the measured parameters of fiber properties, i.e., fiber length at $2.5 \%$ S.L., Strength, elongation and micronair reading and are in agreement with the mentioned results in the work of Sharma and Agarwal (1992) who showed the effect of applied of fenvalarate and cypermethrin on the fiber quality and seed cotton; expressed in a higher oil content in seeds of the treated cotton, higher fibre length, fibre strength at the $50 \%$ boll formation stage. El-Mallah and Emam (1998) stated that the involvement of pyrethroids in the applications of bi and / or tri sequent nutrients sprays, like Baythroid ${ }^{\circledR}$ with Greenzit $\mathrm{Sp}_{100}$ and Greenzit N.P.K / Neem oil increased all the measured fiber properties especially fiber length, tenacity, elongation and micronair. Also, Munirathnam and Sawadhkar (2008) showed that the application of the recommended dose of fertilizers at rate of $100 \%$ (40 : 20: $20 \mathrm{Kg} \mathrm{N.P.K)} \mathrm{or} \mathrm{/} \mathrm{and} \mathrm{TNAU} \mathrm{culture} \mathrm{recorded} \mathrm{the} \mathrm{highest} \mathrm{values}$ for fiber strength. In addition, Arif et al. (2019) found that the Exogenous application of MLE (Moringa Leaf Extract) has a positive effect on photosynthetic and enzymatic activities that improve the efficiency of nutrients that are utilized, thereby improving the growth, seed cotton yield and quality of cotton cultivars tested. Hussain et al. (2020) suggested that the foliar application of $\mathrm{K}_{2} \mathrm{SO}_{4}$ as a source and method of $\mathrm{K}$ fertilizer application might be opted to improve the seed cotton yield, fiber quality and net returns under the arid climate.

\section{CONCLUSION}

It could be concluded from the aforementioned results of the present investigation that the foliar treatments of each of Novatrin/ Radiant ${ }^{\circledR}$, Novatrin/ Super Mix and Novatrin/ Super Mix/Radiant ${ }^{\circledR}$ were high efficient against the spiny bollworm infestation, gave higher increase in cotton yield, improved and enhanced the quality of cotton fiber. 


\section{REFERENCES}

Abd El-Rahman, kh. A (1999). New approach for the control of the pink bollworm, Pectinophora gossypiella (Saund.) (Lepidoptera : Gelechiidae) using pheromones and insecticide. Ph.D. Fac. Agric., (Saba-Bacha), Alex. Univ., Egypt.

Abdel-Aziz and A. Mahasen (2002). The effect of potassium Fertilizers Ascorbic Acid and salicylic acid on inducing resistance in cotton plants Gossypium barbadens L. against the spiny bollworm Earias insulana (Boisd.). $2^{\text {nd }}$ international Conference, plant Porotection Reserch Institute, Cairo, Egypt, 21-24 Decembre,871-876.

Abdel-Rhman, K.A. (2004). Effect of certain bio and chemical insecticides on the incidence of bollworms, physiological and yield parameters of cotton plants. Adv. Agric. Res., 9: 125-136.

Arif, M., S.H.S. Kareem, N.S. Ahmed, N. Hussain, A. Yasmeen, A. Anwar, S. Naz, J. Iqbal, G. A. Shah and M. Ansar (2019). Exogenously Applied BioStimulant and Synthetic Fertilizers to Improve the Growth, Yield and Fiber Quality of Cotton. Sustainability, MDPI, Open Access Journal, 11(7):1-14. doi:10.3390/su11072171.

Awad, H.A. (1982). Toxicological and histopathological studies of certain new group of pesticides against pink bollworm and some of its beneficial enemies. Ph.D. Thesis, Faculty of Agric., Menofiya Univ., Shebin ELKom, Egypt.

Bajya, D.R., D. Monga and M.P. Tyagi (2010). Seasonal monitoring of Insecticide resistance in Helicoverpa armigera on cotton and chickpea. Indian J. Plant Prot. 38: 41-46.

Balakrishnan, N., R.K.M. Baskaran and N.R. Mahadevan (2005). Evaluation of management modules of bollworms on cotton under rain fed conditions Annals, plant Protection, Sci., 13 (2): 373-378.

Chandramani P., R. Rajendran, C. Muthiah and C. C Hinniah Chinniah (2010). Organic source induced silica on leaf folder, stem borer and gall midge population and rice yield. Journal of Biopesticides, 3(2): 423-427.

Dhawan, A.K; A.J. Sindhu And G.S. Simwat(1998). Monitoring the seasonal abundance of cotton bollworms with pheromone traps. Indian J. Ecol., 23:129-131.

El-Tabbakh, S.S. (2002). Effect of some fertilizer and insecticidal treatments on growth, yield, yield components and quality of two cotton cultivars. Elexandria J. Agric. Res., 47 (2): 61-72.

EI-Mallah, M.I. and G.M.I. Emam (1998). Effect of P and K fertilization on cotton yield, seed, fiber and yarn quality. Egypt. J. Appl. Sci., 13 (8): 100-112.

El-Naggar, A.Z (2003). Evaluation of certain new approaches of control measures in an integraded pest management program of cotton bollworms. Ph.D.

Fac. Agric., (Saba-Basha), Alex. Univ., Egypt.

El-Naggar, A.Z. (1998). Evaluation of certain foliars and micro-elements in an Integrated Pest Management (IPM) program to control cotton bollworms. M.Sc. Thesis, Faculty of Agriculture, Alexandria University, Egypt. 
El-Naggar, A.Z. (2009). Efficacy of some foliar fertilizers and alternative chemicals on the spiny bollworm, Earias insulana(Boisd.) larvae (Lepidoptera: Noctuidae). Alexandria J. Agric. Res., 54: 139-146.

El-Naggar, A.Z., Gehan, M. Ibrahim and E.I. El-Agamy (2008). Toxicological and biochemical effects of some foliar nutrients and alternative compounds on the spiny bollworm, Eearias insulana (Boisd.) (lepidoptera: Noctuidae) in relation to larval electrophoresis. J. Adv. Agric. Res. (Fac. Ag. Sba Basha), 13(4): 607-627.

El Sabagh, A., A. M. Omar, M. El Menshawi and S. El Okkia; (2018). Foliar Application of Organic Compounds Stimulate Cotton (Gossypium barbadense L.) to Survive Late Sown Condition. De Gruyter. Open Agriculture., 3(1) 684-697.

Eman, M. M. Radwan, M. A. El-Malla, M. A. Fouda and R. A. Soliman Mesbah(2018). Appraisal of Positive Pesticides Influence on Pink Bollworm Larvae, Pectinophora gossypiella (Saunders). Egypt. Acad. J. Biolog. Sci., 10(1): 37-47.

Gogi M.D., J.M. Arif, M. Asif, Z. Abdin, H.M. Bashir, M. Arshad, A.M. Khan, Q. Abbas, R.M. Shahid and A. Anwar (2012). Impact of nutrient management schedules on infestation of Bemisia tabaci on and yield of non BT- cotton (Gossypium hirsutum) under unsprayed conditions. Pakistan Entomologist, 34(1):87-92.

Hearn, A.B. and G.P. Fitt (1992). Cotton cropping systems. In: Pearson, C. (Ed.), Field Crop Ecosystems of the World. Elsevier Press، Amsterdam, pp. 85-142.

Hussain, M., A.F. Tariq, A. Nawaz, M. Nawaz, A. Sattar, S. Ul-Allah and A. Wakeel (2020). Efficacy of fertilizing method for different potash sources in cotton (Gossypium hirsutum L.) nutrition under arid climatic conditions. PLoS one, 15(1): e0228335. https://doi.org/10.1371/journal. pone.0228335.

Hussin, N.M., F.F. Shalaby, E.F. El-Khayat, S.M. Tawfik and M.S. Salem (2002). Effect of certain agrochemicals on cotton growth and bollworms infestation during three successive seasons at Kalubia Governorate, Egypt. Proceedings of the 2nd International Conference, Plant Protection Research Institute, December 21-24, 2002, Cairo, Egypt,pp:854-865.

Kiran, B., A.K. Sood, V. S. Pathania and S. Thakur (2018). Effect of plant nutrition in insect pest management: A review. Journal of Pharmacognosy and Phytochemistry, 7(4): 2737-2742.

Kranthi, K. R. and G. D. Stone (2020). Long-term impacts of Bt cotton in India. Nature Plants, 6(3): 188-196.

Kumar R., N. Kumawat and Y. K. Sahu (2017). Role of Biofertilizers in Agriculture. Pop. Kheti., 5(4): 63-66. 
Mesbah, H.A., M.M. Ibrahim, E.H. Tayeb, A.Z. El-Naggar and H.M. El-Nimr (2000). Plant health, a new approach for the attainment of tolerant plants to pests infestation: Effect of fertilization and foliar application of nutritive elements on the infestation of cotton with bollworms. Adv. Agric. Res., 5: 1437-1454.

Mesbah, H.A, Kh. A. Abdel-Rahman, A.Z. El-Nagaar and A.A. Mabrouk (2009). New approach for evaluating the use of foliar fertilizres, alternative chemical compounds and release of Trichogramma evanescens in an Integrated Pest (Lepidoptera: Gelechidae) in organic and conventional cotton plants. Minufiya J. Agric. Res. 34 No, 1(2): 253-267.

Munirathnam, P. and S.M. Sawadhkar (2008). Studied on the effect of fertilizers and bio-inoculants on yield and quality of fiber in cotton. J. Cotton Res. and Development, 22 (1): 62-65.

Ramalakshmi, A. and S. A. Raj (2008). Effect of inoculation of biofertilizers on cotton growth and yield. Journal of Soils and Crops, 18(2): 273-278.

Sharma. J. P. and R. A. Agarwal (1992). Effect of insecticidal application on the fibre quality, seed cotton and carryover of Pectinophora gossypiella (Saund) J. Insects Sci., 5 (2):153-156.

Snedecor, G.W. and W.G. Cochran (1967). Statistical Methods. 6th Edn., Oxford and IBH Publishing Co. Pvt. Ltd., New Delhi, India, Pages:593.

Torres-Olivar, V., O.G.Villegas-Torres, M.L. Domínguez-Patino, H. SoteloNava, A. Rodríguez-Martínez , R.M. Melgoza-Alemán, I. Alia-Tejacal (2014). Role of nitrogen and nutrients in crop nutrition. J. Agric. Sci. Technol., 4: 29-37.

Treshow, M. (1970). Environment and Plant Response. McGraw Hill Book Company, New York, USA., Pages: 422.

Wei, J., L. Zhang, S. Yang, B. Xie, S. An and G. Liang (2018). Assessment of the lethal and sublethal effects by spinetoram on cotton bollworm. PLoS One, 13(9):1-11. e0204154. https://doi. org/10.1371/journal.pone.0204154 PMID: 30216388 


\title{
الملخص العربي
}

\section{اتجاهات حديثة لمكافحة ديدان اللوز القرنقلية والشوكية من خلال بعض وبائل المكافحة الحيوية والمركبات الكيميائية واثز ذلك علي خصائص القطن}

\author{
حسن علي مصباح(') علي زكريا النجار(r) احمد عبدالفتاح عبدالمجيد(1) \\ هند محمود عبدالحليم ابوزيد(r) \\ (1) قسم وقاية النبات- كلية الزراعة (سابابانشا) - جامعة الاسكندرية- مصر \\ (Y) معهر بحوث وقاية النباتات- مركز البحوث الزراعية- الاسكندرية- مصر
}

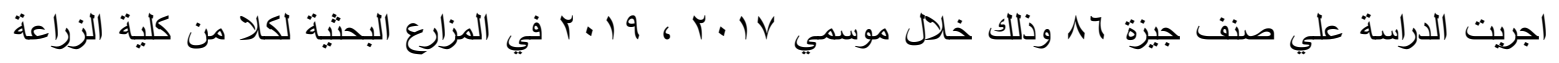
ساباباشا و الثاطبي - محافظة الاسكندرية-مصر .

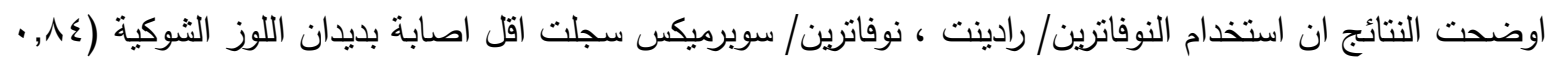

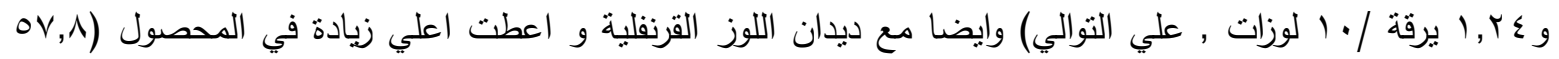
قنطار / فدان). علاوة علي ذلك النوفاترين/سوبرميكس، سوبر ميكس/ رادينت سجلت اقل نسبة خسائر في المحصول (

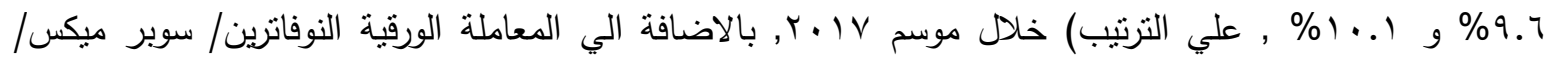
رادينت ، سوبر ميكس/ بوتاسين اف / رادينت كان اكثر كفاءة علي تقليل الاصابة بديدان اللوز الشوكية ( سه, · و و

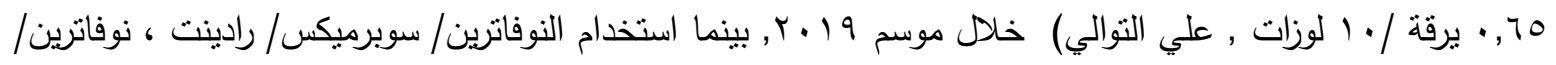

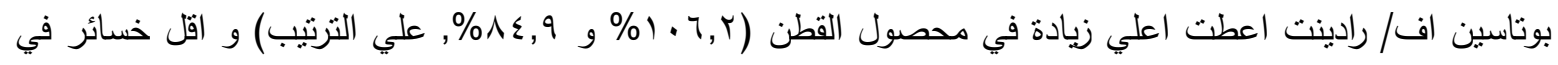
المحصول خلال موسم 9 أـ ب, بينما استخدام المعاملة الورقية النوفاترين/ سوبر ميكس اعطت اعلي زيادة في طول

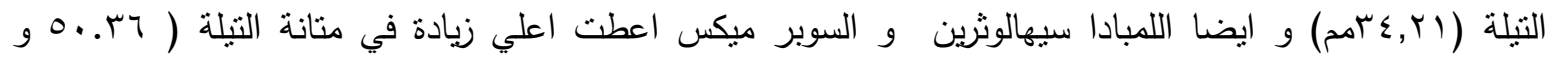
7 ا, •0 جم/ تكس, علي الترتبب) و اعلي قيمة لقراءة الميكرونير تم الحصول عليها من استخدام المعاملة سوبر

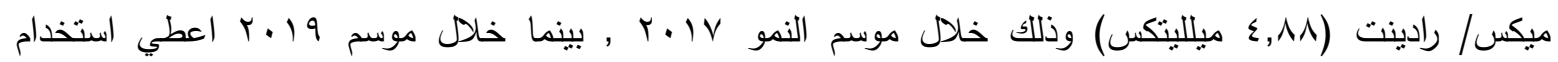

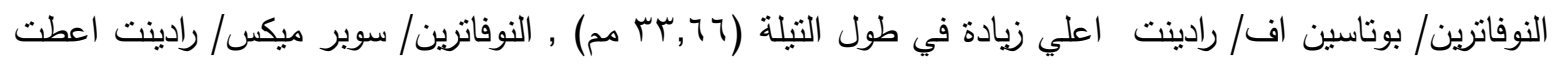

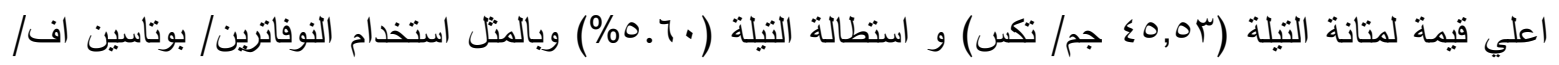

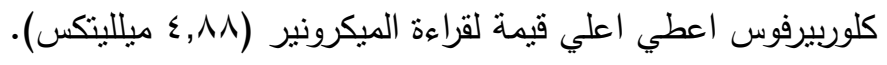

